\title{
Compare the Changes of Groundwater Type and Microbial Community in Four Shallow Aquifers Affected by Seawater Intrusion in the East Coastal of Pearl River Delta
}

\author{
Kang Yang ${ }^{1}$, Linjie $\mathrm{Hu}^{1}$, Shengcai Huang ${ }^{1}$, Can Liu ${ }^{1}$, Liang Feng ${ }^{1}$, and Jianmei Cheng ${ }^{1}$ \\ ${ }^{1}$ China University of Geosciences
}

December 14, 2021

\begin{abstract}
Seawater intrusion has become a serious natural disaster in coastal regions around the world. Four shallow groundwater aquifers of Pearl River were sampled to study the changes of groundwater types and microbial communities caused by seawater intrusion. Seawater intrusion caused significantly increased cations ( $\mathrm{Na}+, \mathrm{K}+, \mathrm{Ca} 2+, \mathrm{Mg} 2+)$ and anions (Cl-, $\mathrm{SO} 42-$, $\mathrm{HCO} 3-)$, and the groundwater type turned from $\mathrm{HCO} 3-\mathrm{Ca}$ to $\mathrm{Cl}^{*} \mathrm{HCO} 3-\mathrm{Na}^{*} \mathrm{Ca}$ and $\mathrm{Cl}^{*} \mathrm{SO} 4-\mathrm{Na} * \mathrm{Mg}$. The composition and diversity of groundwater geochemistry changes. Gammaproteobacteria species and Alphaproteobacteria species are dominant species, and the salinity of groundwater is the main environment factor that affect the relative abundance. The $\alpha$-diversity of microbial community in three types groundwater are significantly different $(\mathrm{P}=0.002, \mathrm{R} 2=0.959)$. The correlation between species in class level with different ions were also observed. Aeromonadales, Vibrionales, Alteromonadales and Oceanospirillales have a significant positive correlation with $\mathrm{Cl}-, \mathrm{SO} 42-, \mathrm{Na}+$ and $\mathrm{Mg} 2+(\mathrm{P}<0.05)$ in $\mathrm{Cl}^{*} \mathrm{SO} 4-\mathrm{Na} * \mathrm{Mg}$ type, while in $\mathrm{Cl}^{*} \mathrm{HCO} 3-\mathrm{Na} * \mathrm{Ca}$ type groundwater, Vibrionales and Oceanospirillales have positive correlations with $\mathrm{Cl}-, \mathrm{Na}+, \mathrm{Ca} 2+$, but negative correlations with HCO3-. Aeromonadales and Alteromonadales are opposite of this. The results demonstrate that groundwater type is the main factors influence the correlation between species and environments, other geophysical factors have weak influence. This shift of shallow groundwater type and microbial community under seawater intrusion were studied for the first time, it is momentous for forward exploration of groundwater microbial ecology in the coastal area under the background of seawater intrusion.
\end{abstract}

Compare the Changes of Groundwater Type and Microbial Community in Four Shallow Aquifers Affected by Seawater Intrusion in the East Coastal of Pearl River Delta

Kang Yang ${ }^{1}$, Linjie $\mathrm{Hu}^{3}$, Can $\mathrm{Liu}^{3}$, Shengcai Huang ${ }^{3}$, Liang Feng ${ }^{1,} 3^{*}$, Jianmei Cheng ${ }^{2,} 3^{*}$

${ }^{1}$ State Key Laboratory of Biogeology and Environmental Geology, China University of Geosciences, Wuhan 430074, China

${ }^{2}$ Key Laboratory of Environmental and Water Science in the Yangtze River Basin of Hubei Provience, China University of Geosciences, Wuhan 430074, China

${ }^{3}$ School of Environmental Studies, China University of Geosciences, Wuhan 430074, China

${ }^{*}$ Corresponding author:

Liang Feng

E-mail: fengliang@cug.edu.cn

Address: State Key Laboratory of Biogeology and Environmental Geology, China University of Geosciences, Wuhan 430074, China 
Jianmei Cheng

E-mail address:jmcheng@cug.edu.cn

Address: School of Environmental Studies, China University of Geosciences, Wuhan 430074, China

\section{Abstract}

Seawater intrusion has become a serious natural disaster in coastal regions around the world. Four shallow groundwater aquifers of Pearl River were sampled to study the changes of groundwater types and microbial communities caused by seawater intrusion. Seawater intrusion caused significantly increased cations $\left(\mathrm{Na}^{+}, \mathrm{K}^{+}, \mathrm{Ca}^{2+}, \mathrm{Mg}^{2+}\right)$ and anions $\left(\mathrm{Cl}^{-}, \mathrm{SO}_{4}{ }^{2-}, \mathrm{HCO}_{3}{ }^{-}\right)$, and the groundwater type turned from $\mathrm{HCO}_{3^{-}}$ $\mathrm{Ca}$ to $\mathrm{Cl}^{*} \mathrm{HCO}_{3}-\mathrm{Na}^{*} \mathrm{Ca}$ and $\mathrm{Cl}^{*} \mathrm{SO}_{4}-\mathrm{Na} * \mathrm{Mg}$. The composition and diversity of microbial communities in groundwater dramatically changed along with the groundwater geochemistry changes. Gammaproteobacteria species and Alphaproteobacteria species are dominant species, and the salinity of groundwater is the main environment factor that affect the relative abundance. The $\alpha$-diversity of microbial community in three types groundwater are significantly different $\left(P=0.002, \mathrm{R}^{2}=0.959\right)$. The correlation between species in class level with different ions were also observed. Aeromonadales, Vibrionales, Alteromonadales and Oceanospirillales have a significant positive correlation with $\mathrm{Cl}^{-}, \mathrm{SO}_{4}{ }^{2-}, \mathrm{Na}^{+}$and $\mathrm{Mg}^{2+}(P<0.05)$ in $\mathrm{Cl} \cdot \mathrm{SO}_{4}-\mathrm{Na} \cdot \mathrm{Mg}$ type, while in $\mathrm{Cl} \cdot \mathrm{HCO}_{3}-\mathrm{Na} \cdot \mathrm{Ca}$ type groundwater, Vibrionales and Oceanospirillales have positive correlations with $\mathrm{Cl}^{-}, \mathrm{Na}^{+}, \mathrm{Ca}^{2+}$, but negative correlations with $\mathrm{HCO}_{3}{ }^{-}$. Aeromonadales and Alteromonadales are opposite of this. The results demonstrate that groundwater type is the main factors influence the correlation between species and environments, other geophysical factors have weak influence. This shift of shallow groundwater type and microbial community under seawater intrusion were studied for the first time, it is momentous for forward exploration of groundwater microbial ecology in the coastal area under the background of seawater intrusion.

\section{Keywords:}

Pearl River Delta, seawater intrusion, microbial community, groundwater type

\section{INTRODUCTION}

Groundwater resources are not only important domestic water resources for coastal residents, but also important parts of coastal ecosystems (Griebler \& Lueders, 2009; Kwon, Park, Park, Kang, \& Woo, 2021; K. Liu, Jiao, \& Gu, 2014; Unno et al., 2015). When groundwater is discharged to the ocean in the aquifer profile, the terrestrial nutrients will be brought into the ocean. Meanwhile, the substances of seawater diffuse in the fresh water. In the salt and fresh water mixed zone around the underground estuary, the water environment gradient will change drastically, such as salinity, nutrient concentration, dissolved matter concentration, etc. (D. Adyasari, Hassenruck, Montiel, \& Dimova, 2020; Dini Adyasari, Oehler, Afiati, \& Moosdorf, 2019; Babu et al., 2021; Henriques et al., 2006). Changes in groundwater salinity will affect the primary productivity of coastal ecosystems, so the salinity of mixed zone is the main environmental factor that affects the health of coastal ecosystems. Research has found that when coastal regions are subject to seawater for a long period, nutrients in the environment will undergo a significant migration process under the salinity gradient. For example, a large amount of carbon and nitrogen in soil will transfer to water, and the loss of nitrogen will cause a reduction in the biomass of terrestrial plants by nearly $90 \%$, and increased nitrate and sulfate in pore water, resulting in a $44 \%$ reduction in groundwater biomass (Hwang, Lee, \& Kim, 2005; Widney et al., 2019).

The increase in population density in coastal areas has changed the use of land, increased the groundwater demand, and also aggravated groundwater pollution, in which seawater intrusion has become the main environmental disaster (Chandrajith et al., 2016; Jankowski, Tornqvist, \& Fernandes, 2017; Qi \& Qiu, 2011; Venancio et al., 2018). According to the Ghyben-Herzberg principle, the seawater will be inserted below the head of freshwater in a wedge shape because of the relatively high density in salt-fresh water mixed zone (Ghyben, 1988; Herzberg 1901). The ecological environment of the mixed zone is complex, as the location, shape, and water chemistry characteristics are affected by various natural environments(Kim et al., 2006; 
Llopis-Albert \& Pulido-Velazquez, 2014; Sakr, 1999; Werner et al., 2013). Microorganisms are important organisms in groundwater ecosystem, and the composition and functional diversity of microbial communities are affected by environmental factors, include $\mathrm{pH}$ and total dissolved solid (Campbell \& Kirchman, 2013; Chen et al., 2019; Goldscheider, Hunkeler, \& Rossi, 2006). Marina Héry et al. found microbes can produce a large amount of organic acid when use organic carbon to obtain energy in the mixed zone (Hery et al., 2014). The acidic groundwater corrodes the carbonate aquifer, which expands the degree of seawater intrusion. It has been proven that the carbon cycle process involving microorganisms is an important driving force for the development of seawater intrusion in the carbonate coastal zone. Given that most previous research were based on random sampling in the seawater intrusion areas, and analysis of hydrogeology of groundwater along with microbiology has not been carried out, the impact of seawater intrusion on the microbial community in the coastal groundwater profile has not been deeply understood yet.

The Pearl River Delta (PRD) is located at the southernmost tip of China, which has become the most prosperous economic regions in China past few decades. It is the estuary of the Pearl River, the largest river in China's subtropical region, transporting surface water to the South China Sea. Many studies have found that a large number of pollutants are discharged into the abundant surface water. With the hydraulic exchange with groundwater, the pollutant enters the groundwater aquifer and causes groundwater pollution, and $50 \%$ cannot be directly used(Jiao et al., 2010; Lu, Ni, Liu, \& Zeng, 2009; Mai, Lai, Li, Peng, \& Wang, 2018).

Stable isotope methods have shown that ancient seawater intrusion caused groundwater salinity increase in part of the PRD (Ya Wang \& Jiao, 2012; Y. Wang, Jiao, Cherry, \& Lee, 2013). Nowadays, land reclamation and groundwater overexploitation have led modern seawater entering freshwater along aquifers, rivers and other groundwater replenishment pathways (Zong, Huang, Switzer, Yu, \& Yim, 2009). Groundwater salinization have changed the composition and functional diversity of microbial communities, and some studies found that the sensitivity to the environmental factors change of microbial species can indicate the degree of seawater intrusion, such as Oceanospirillales and Alteromonadaceae (Chen et al., 2019; Lee, Wang, Wang, Gu, \& Jiao, 2018; Y. Liu et al., 2020; S. Sang et al., 2018; Zhang, Qi, Li, Hu, \& Dai, 2021). Previous studies were mostly based on the west side of the PRD where surface water is abundant. However, the seawater intrusion situation also serious in the east area, but related research was less carried out due to relatively poor surface water.

To this end, shallow groundwater samples were collected from the east PRD and subjected to high-throughput sequencing of the $16 \mathrm{~S}$ rRNA gene. The main focus of this study are (a) to determine the degree of seawater intrusion in the east PRD, (b) to investigate the effects of seawater intrusion on microbial communities, (c) to explore the relationship between microbial and environments in different type groundwater.

\section{MATERIALS AND METHODS}

\section{Study area}

As shown in Figure 1A, the study area is located in the area of $22^{\circ} 76^{\prime}$ to $22 \operatorname{deg} 50^{\prime} \mathrm{N}$ and $113 \mathrm{deg} 75^{\prime}$ to $113 \mathrm{deg} 96$ ' $\mathrm{E}$, which is in the east of PRD. Meteorological data show that the annual average temperature is 22.4 , sunshine duration is 1933.8 hours, and total radiation is $54.2 \mathrm{mj} / \mathrm{m}^{2}$. The average rainfall is about $1700 \mathrm{~mm}$, of which the rainy season (May to September) and dry season (October to next April) account for $78 \%$ and $22 \%$, respectively. The prevailing wind directions are southeast-east and north-northeast.

The geology of the study area has been explored in details by predecessors. Generally, sedimentary and granite strata constitute together, and the regional tectonic activities are active, resulting in the strata of other eras were destroyed by metamorphism in varying degrees except that the Mesozoic to Cenozoic strata is relatively complete. The coastal zone is dominated by marine sediments and river alluvial. The terrain changes are higher in the northeast and lower in the south, and the slope varies from 1 to $4 \mathrm{deg}$.

There are four shallow groundwater aquifers in this study, named DBH, XXH, PM1 and PM2, respectively. As shown in Figure 1B, Profile DBH is located in the northwest of Shenzhen city, with the groundwater 
buried depth being 1.6 to $3.5 \mathrm{~m}$. The change of the water level in the offshore section is obviously affected by the tide level of the sea. The main replenishment channels are atmospheric precipitation, surface runoff and lateral seepage in adjacent areas, and the flow rate is low. Profile XXH is located in the west, and there is no Quaternary aquifer in the offshore area, a certain thickness of Quaternary pore water aquifer in the upstream. Buried depth of groundwater is $3 \mathrm{~m}$, and the replenishment channels are as some as profile DBH. Profile PM1is located in the southeast of profile XXH, the groundwater level is shallower than others, and the thickness of the aquifer varies greatly. Profile PM2 is perpendicular to PM1, and the depth of the groundwater level in the north is 1.2 to $4.2 \mathrm{~m}$, mainly phreatic water with some confined water. For comparison, the groundwater level in the south is shallower, and the thickness of the aquifer varies greatly.

\section{Sample collection}

Twelve groundwater samples were collected in November, 2019. Three groundwater wells were selected for each profile as shown in Fig. 1B, and the distance between each sampling point is as large as possible to ensure that the groundwater chemical environment changes along the gradient. Before sample collection, a submersible pump was used to pump the groundwater out at three times the infiltration replenishment. After the recharge was completed, a portable mete $(\mathrm{HACH}, \mathrm{CO}, \mathrm{USA})$ connected with appropriate probes was used to analyze the geochemical parameters (i.e., $\mathrm{pH}$, ORP, EC, and DO) of each groundwater sample in the field. Cations and anions of samples were filtered through a $0.45-\mu \mathrm{m}$ membrane in situ for laboratory measurement. The former collected into an acid-washed $50-\mathrm{mL}$ high-density polyethylene bottle and the filtered groundwater acidified to $\mathrm{pH}<2$ using ultrapure $\mathrm{HNO}_{3}$, and the latter collected into a precleaned bottle without other treatments (Ma et al., 2019). In addition, $500 \mathrm{~mL}$ unfiltered sample was collected for unstable $\mathrm{HCO}_{3}$-and $\mathrm{CO}_{3}{ }^{2-}$ measurement through titration within 24 hours, and the test accuracy was \pm 1 $\mathrm{mg} / \mathrm{L}$.

As for the microbial biomass in groundwater. $1 \mathrm{~L}$ groundwater was sampled after the bottle was washed three times with sampling groundwater, and three biological replicates were collected at each sampling site. The sampled groundwater filtered through $0.22-\mu \mathrm{m}$ microporous membrane (Whatman, UK), and then the biomass-containing membranes were placed in 50-mL sterile tubes. Before transported to geological microbiology laboratory of China University of Geosciences (Wuhan), the membranes were frozen and stored in dry ice. In laboratory, maintained at $-20^{\circ} \mathrm{C}$ refrigerator for further analysis.

\section{Geochemical analysis}

The cations test $\left(\mathrm{K}^{+}, \mathrm{Na}^{+}, \mathrm{Ca}^{2+}, \mathrm{Mg}^{2+}\right)$ in groundwater were subjected to inductively coupled plasma emission spectroscopy (ICP-OES, Thermo, USA), and the anions test $\left(\mathrm{Cl}^{-}, \mathrm{NO}_{3}{ }^{-}, \mathrm{SO}_{4}{ }^{2-}\right)$ were subjected to ion chromatography (883 Basic IC plus, Metrohm, Switzerland). All geochemical tests were finished in the Three Gorges Research Center for Geohazards, Ministry of Education (CUG, Wuhan, China). The total dissolved solids (TDS) of groundwater is calculated by adding the above seven ions concentration and half of the bicarbonate concentration (Farid, Trabelsi, Zouari, Abid, \& Ayachi, 2013).

\section{DNA extraction and PCR amplified}

The total DNA of the filter microorganisms was extracted by following the instruction of the Fast DNA Soil-Direct Kit (MoBio Technologies Inc, CA, USA), and the DNA quality was evaluated by $1 \%$ agarose gel electrophoresis and nanodrop electrophoresis (Thermo Fisher Scientific, MA, USA). Using the extracted DNA as the template, the V4 region in the $16 \mathrm{~S}$ rRNA sequence was amplified by PCR using universal amplification primers 515F (5'-GTGCCAGCMGCCGCGGTAA-3') and 806R (5'-GGACTACHVGGGTWTCTAAT-3'). The detailed PCR conditions were described in a previous study(J. Yang, Jiang, Wu, Liu, \& Zhang, 2016). Briefly, a 12-bp barcode sequence was added between the sequence adaptor and the pre-primer to distinguish samples from different sources. Each membrane was subjected to triplicate PCRs and purified using DNA Gel Extraction Kit (Axygen, Union City, CA, USA). The specific PCR process is shown in Table S1.

\section{Sequencing and data processing}

The library was constructed according to the standard procedure of Illumina library construction after 
amplification, and then high-throughput sequencing was performed on the constructed microbial amplicon library using the Illumina Hiseq2500 platform in MegiGene Technology Co., Ltd. (Guangzhou).

The raw reads processing includes: using Trimmomatic (V0.33) to perform quality-trimmed, then FLASH (V1.2.11) was used to assembly the paired-end into effective clean tags (the minimum overlap length to 10-bp, and the maximum allowable mismatch ratio in the overlap region to 0.1 were set). According to the barcode information, use Mothur (V1.35.1) software to carry out the final quality control of the spliced sequence and remove the chimera. Use USEARCH (V10, http://www.drive5.com/usearch) software to cluster the sequences through the uclust algorithm (Schloss et al., 2009).

According to sequence similarity, a 0.03 identity cutoff is set to cluster the sequences to the operational taxonomic units (OTUs), and the chimeric sequences were removed with the aid of USEARCH (v10,http://www.drive5.com/usearch). The representative sequence of each OTU was selected and compared with the Silva database (v.132) to obtain the species annotation information of all OTUs.

\section{Statistical analysis}

Alpha diversity and beta diversity are analyzed using Mothur (v.1.42.0). Alpha diversity index includes Shannon index, Simpson index and Chao1. Beta diversity analysis is used to investigate the difference in microbial composition of different samples. The principal coordinate analysis (PCoA) method based on the Bray-Curtis similarity matrix compares the community composition dissimilarity between different samples, and the principal component analysis (PCA) compares the correlation between different samples and the main environmental factors. The visualization process of the above analysis is implemented by the "vegan" and "ggplot2" packages of R (v3.5.3). Spearman correlation analysis was performed using SPSS software (IBM Corp., Armonk, NY, USA) to determine the correlation between water chemistry parameters and microbial species.

The 16S rRNA gene sequences have been submitted to the National Center for Biotechnology Information (NCBI) Gene Bank under the SRA accession numbers SAMN18354819-SAMN18354830.

\section{RESULTS}

\section{Hydrogeological characteristics and environmental parameters}

The hydrogeological characteristics of each aquifer shown in Figure 1B. Briefly, profile DBH is dominated by pore water aquifer of Quaternary and fissure aquifer of granite, among which the thickness of Quaternary aquifer is 2.2 to $4.2 \mathrm{~m}$, and the lithology is mainly gravel sand and coarse sand. With regard to profile $\mathrm{XXH}$, the thickness of Quaternary aquifer is 5.2 to $9.6 \mathrm{~m}$, and the lithology is mainly medium-coarse sand and gravel sand. Profile PM1 is dominated by Quaternary pore water aquifer, and its lithology is mainly medium sand. Bedrock fissure aquifer is located in the north of profile PM2, and its lithology is dominated by fine-coarse grained porphyritic biotite granite. In comparison, the lithology is dominated by medium-coarse of Quaternary aquifer in the south.

The geochemical characteristics of all samples were shown in Table 1. The $\mathrm{pH}$, ORP, DO, and EC values range from 5.56 to $7.81,-94.5 \mathrm{mV}$ to $201 \mathrm{mV}, 1.76 \mathrm{mg} / \mathrm{L}$ to $7.73 \mathrm{mg} / \mathrm{L}$, and $65.9 \mu \mathrm{s} / \mathrm{cm}$ to $34800 \mu \mathrm{s} / \mathrm{cm}$, respectively. The shallow groundwater was divided to freshwater $(0-1 ; \mathrm{F})$, brackish water (1-10; B), and saltwater (> 10; S) according to the TDS concentration (Shilei Sang et al., 2019; Teng et al., 2014). The results indicated that there are seven freshwater sites, two brackish water sites, and three saltwater sites. Besides, the change trend of TDS is consistent with EC that the higher TDS concentration is accompanied with the higher EC value (Kima et al., 2003).

\section{Microbial community diversity of groundwater}

According to Table S3, a total of 2,512,939 qualified sequence reads were obtained in NGS analysis. On average, each groundwater site contained 64,248 sequence reads, which were divided into 10,074 OTUs. Among them, PM1.1 had the least number of 2064, and XXH3 had the highest number of 4161. 
The $\alpha$-diversity of microbial communities in each sample site were shown in FIGURE 2. The Shannon index and the Simpson index ranged from 2.84 to 4.99 and from 0.02 to 0.28 , respectively. Site XXH2 has the highest Shannon and the lowest Simpson. On the contrary, site DBH1has the lowest Shannon and highest Simpson. The reads of each site range from 59,941 to 67,808. Site PM1.3 and PM2.2 has the least number and the most number of sequences, respectively. The Chao 1 ranges from 1,189 to 2,595, with PM1.1 and DBH1 being the lowest and highest sites, respectively.

According to the Geben-Herzberg principle, site DBH2 is located in the mixed zone of salt-fresh water on the profile DBH. However, the microbial community diversity in DBH are different from the results of previous studies. Marina Héry et al. found that the mixed zone has the highest abundance and evenness in a seawater intrusion area in the Mediterranean Sea (Hery et al., 2014). Chen Lin et al. found that the abundance and evenness in the mixed zone are both high (Chen et al., 2019). In contrast, the evenness of DBH2 is the lowest, and the abundance is also lower than freshwater in this study.

\section{Microbial community composition in different type of groundwater}

The microbial community composition in groundwater was studied at the level of class and genus, respectively. As shown in Figure 3A, Gammaproteobacteria species and Alphaproteobacteria species, which belong to Proteobacteria species, are the main microbial species in groundwater. The relative abundances of Gammaproteobacteria species in the sites of profile DBH are 35.3\% (DBH1), 63.6\% (DBH2) and 80.7\% (DBH3), respectively. Bacteroidia species, which under Bacteroidetes species, is another microbial population that exists widely in groundwater environment. The most abundant point is DBH1 followed by PM1.1, which are $28.4 \%$ and $12.8 \%$, respectively. The points with low relative abundance are DBH3 and PM2.2, which are $0.8 \%$ and $0.4 \%$, respectively.

The relative abundance of Gammaproteobacteria changes along with the salinity gradient in groundwater of profile DBH, which is consistent with previous studies found that Gammaproteobacteria species is more adaptable to high salinity environments(Paver, Muratore, Newton, \& Coleman, 2018; Zhang, Hu, Ren, \& Zhang, 2018; Zhang et al., 2021).

Top 15 species in genus level was shown in Figure 3B.Hydrogenophaga species are widely present in groundwater environment. XXH2 has the highest relative abundance at $52.3 \%$, and DBH3 has the lowest relative abundance at $0.41 \%$. The relative abundance of Marinobacter species in DBH3 is the highest (40.7\%), same as Vibrio species, with a relative abundance of $19.4 \%$.

The PCoA results showed that the $x$-axis (PCoA 1) and the $y$-axis (PCoA 2) explained $20.29 \%$ and $15.3 \%$ of the microbial community variance, respectively, which shown in Figure 4. Site XXH3, PM2.1 and PM2.2 are clustered together, and the distances between other sites are farther, indicating that the community composition are similar. The site PM2.3, which is affected by seawater intrusion, is far away from other sites, but closer to XXH1 and XXH2. It was noticed that although the profiles XXH and PM2 have different groundwater types, but the community composition are similar.

\section{The contribution of environmental parameters on community structure}

Water type determine the microbial community structure, however, the main ions have different contribution rate.

The results in Figure 5A and Table S4 shown that for samples with $\mathrm{Cl} \cdot \mathrm{SO}_{4}-\mathrm{Na} \cdot \mathrm{Mg}$, single factors of $\mathrm{Cl}^{-}$, $\mathrm{SO}_{4}{ }^{2-}, \mathrm{Na}^{+}$and $\mathrm{Mg}^{2+}$, contribute a negative rate. The two-factor combination, $\mathrm{SO}_{4}{ }^{2-}$ and $\mathrm{Na}^{+}$, have the largest contribution rate of $10.1 \%$, followed by $\mathrm{Cl}^{-}$and $\mathrm{Mg}^{2+}$, with a contribution rate of $6.8 \%$, and the others have a contribution rate less than $5 \%$. The three environmental factor combinations, $\mathrm{SO}_{4}{ }^{2-}, \mathrm{Cl}^{-}$, and $\mathrm{Mg}^{2+}$, have the highest contribution rate of $21.1 \%$, and addition of $\mathrm{Na}^{+}$does not increase the contribution rate, indicating that $\mathrm{Na}^{+}$is the main negatively environment factor that affects the community structure $(P$ $<0.05)$.

Accordingly, the results in Figure 5B and Table S4 shown that for samples with $\mathrm{Cl} \cdot \mathrm{HCO}_{3}-\mathrm{Na} \cdot \mathrm{Ca}$, single 
factor of $\mathrm{Ca}^{2+}$ has the highest contribution rate at $62.2 \%$, followed by $\mathrm{HCO}_{3}{ }^{-}$at $31.4 \%$, and the contribution rates of $\mathrm{Na}+$ and $\mathrm{Cl}^{-}$are $19.3 \%$ and $18.2 \%$, respectively. $\mathrm{HCO}_{3}{ }^{-}$and $\mathrm{Cl}^{-}$, have the largest contribution rate of $36.1 \%$. $\mathrm{HCO}_{3}{ }^{-}, \mathrm{Ca}^{2+}$ and $\mathrm{Na}^{+}$, has a contribution rate of $36.9 \%$. The presence of $\mathrm{Cl}^{-}$makes the contribution rate to a negative value, indicating that the microbial structure is dominated by freshwater species in the $\mathrm{Cl} \cdot \mathrm{HCO}_{3}-\mathrm{Na} \cdot \mathrm{Ca}$ type groundwater, and affected by bicarbonate and Calcium ions concentration mainly $(P$ $<0.05)$.

Although the groundwater types are different, the common contribution rates of the four ions are all negative, and leave a large amount of variance that has not been explained.

\section{DISCUSSION}

\section{The effects of seawater intrusion on the shallow groundwater}

According to the principle of hydrogeochemical (Reddy, Saibaba, \& Sudarshan, 2012; Q. C. Yang, Li, Ma, Wang, \& Martin, 2016), the groundwater type in the study area is mainly $\mathrm{HCO}_{3}$-Ca without considering the seawater stress. Table S2 shown that $\mathrm{HCO}_{3}{ }^{-}$and $\mathrm{Ca}^{2+}$ are the anion and cation having the highest concentrations, which is determined by the natural of the aquifer. The concentration of $\mathrm{Cl}$ - and $\mathrm{Na}+$ in groundwater increases significantly in the profile XXH. Figure 6 indicates that although the TDS concentration of sites in profile XXH does not increase significantly, the groundwater has salinization, and the water type turned to $\mathrm{Cl}^{*} \mathrm{HCO}_{3}-\mathrm{Na} * \mathrm{Ca}$.

In addition to the high concentration of $\mathrm{Cl}^{+}$and $\mathrm{Na}+$ in seawater, $\mathrm{SO}_{4}{ }^{2-}$ and $\mathrm{Mg}^{2+}$ also determine that seawater intrusion will cause serious pollution to groundwater. Taking PM2.2 as the standard, seawater intrusion increased the $\mathrm{Cl}^{-}, \mathrm{Na}^{+}, \mathrm{SO}_{4}{ }^{2-}$ and $\mathrm{Mg}^{2+}$ concentrations in the sites of DDH3, PM1.1, and PM1.2 by an average of 2000, 1000, 400, and 700 times, respectively. According to Figure 6, seawater stress has increased the ion concentration in the groundwater by more than 10 times in site DBH1 to turn the water type to $\mathrm{Cl}^{*} \mathrm{SO}_{4}-\mathrm{Na} * \mathrm{Mg}$, while it still remains the freshwater.

For the phenomenon that the groundwater in profile XXH is under seawater stress but not polluted by seawater directly, there are several possible explanations. First, the estuary of the Xixiang River is blocked by land, which weakens the seawater intrusion by tides. Second explanation might be that the reservoir on the upper of the Xixiang River stabilizes the recharge of groundwater, therefore the pressure of groundwater head and seawater head is dynamically balanced. On the contrary, the situation of groundwater pollution in basin of Dongbao River is seriously.

\section{Correlation between microbial community and water type}

Statistical analysis indicated that the main anions and cations in groundwater (i.e., $\mathrm{Cl}^{-}, \mathrm{Na}^{+}, \mathrm{K}^{+}, \mathrm{Ca}^{2+}$, $\left.\mathrm{Mg}^{2+} ; P<0.05\right)$ have a relatively high relative contribution to the microbial community structure in Table S4. As shown in Figure 7, the PC1 axis and the PC2 axis explain $70.25 \%$ and $11.57 \%$ of the variance, respectively. For saltwater samples with $\mathrm{Cl}^{*} \mathrm{SO}_{4}-\mathrm{Na} * \mathrm{Mg}$ type, there is a significant positive correlation between microbial community and ions in seawater $(P<0.01)$, while it has a negative correlation with ORP. On the contrary, the microbial community of other samples are negatively correlated with all ions, in which ORP is the main environment factor affecting the microbial community structure.

Many studies have found that $\mathrm{pH}$ is the main environment factor affecting the microbial community composition in many environments, includes the groundwater (Cheng et al., 2021; Ham et al., 2021; He et al., 2021; Logares et al., 2009). However, $\mathrm{pH}$ is not the most important environmental factor that affects the change of community structure in this study, because the change of ions by seawater is greater than the change of pH (Crump, Hopkinson, Sogin, \& Hobbie, 2004; Ye, Liu, Du, \& Zhang, 2015).

Microbial species has different correlation with the environmental factor in different water types. As shown in Figure S1 and Table S5, Alteromonadales has a great significant negative correlation with ORP, and a very significant positive correlation with $\mathrm{Cl}^{-}, \mathrm{Na}^{+}$and $\mathrm{Mg}^{2+}(P<0.01)$. In Comparison, Campylobacterales has a very significant negative correlation with $\mathrm{SO}_{4}{ }^{2-}$ and a significant negative correlation with $\mathrm{Cl}^{-}, \mathrm{Na}^{+}$and 
$\mathrm{Mg}^{2+}(0.01<P<0.05)$. For other microbes, Oceanospirillales and Aeromonadales have a very significant negative relationship with ORP, and Rhodobacterales and Rhizobiales have a very significant positive and negative relationship with $\mathrm{SO}_{4}{ }^{2-}$, respectively. As shown in Figure S2 and Table S6, Chitinophagales has a very significant positive correlation with $\mathrm{HCO}_{3}-$, contrastly. Betaproteobacteriales and Flavobacteriales have a significant negative correlation with $\mathrm{Ca}^{2+}$ and DO, respectively, and Sphingomonadales have a significant negative correlation with $\mathrm{DO}, \mathrm{Cl}^{-}$and $\mathrm{Ca}^{2+}$.

\section{Impacts of microbial structure change caused by seawater intrusion}

Table S2 showed that shallow groundwater in profile DBH affected by seawater intrusion. Human activity pollution is also a significant factor, because high nitrate concentration is observed in the DBH1 site. Nitrate enter into the groundwater to participate in the biogeochemical cycle of nitrogen, that is controlled by a variety of environmental factors, such as redox, dissolved oxygen, coupled metal concentration, etc. (Santoro, 2010). Seawater intrusion might change the groundwater environment, including the microbial community structure of sediments (Luther, Sundby, Lewis, Brendel, \& Silverberg, 1997; Smith, Bohlke, Song, \& Tobias, 2015). The process of microbial consumption of nitrate has been accelerated, therefor the nitrate change in sites DBH2 and DBH3 is not correalted with the salinity gradient. The biogeochemical cycle changes caused by seawater intrusion needed further research.

Hydrogenophaga species is a microorganism that has a strong ability to degrade organic pollutants (such as naphthalene) and is highly adaptable to extreme environments (Han Ming Gan, Chew, Tay, Lye, \& Yahya, 2012; H. M. Gan, Shahir, \& Yahya, 2012). Previous studies have shown that in areas with serious organic pollution, there are a large number of Hydrogenophaga species in soil and groundwater. The PCoA results show that Hydrogenophaga in OTU_1 is similar to those in sites of PM2.3, XXH1 and XXH2, may be related to the pollution of groundwater by human activities. This research focuses on the shallow groundwater pollution by seawater and ignores the impact of human activities. Therefore, it is necessary to further study the biogeochemical cycle process in different groundwater type.

Community composition changes have not only changed the biogeochemical cycle process, but also have a prominent impact on human society. PCoA results show that Vibrio in OTU_2 and Marinobacter in OTU_22, two opportunistic pathogens, are closer to site DBH3. Vibrio species have been widely discovered in marine research in recent years (Ashok Kumar et al., 2020; Gyraite, Katarzyte, \& Schernewski, 2019), showing that potential pathogenic bacteria in seawater have become part of the microbial community of shallow groundwater in seawater intrusion areas. In this study, no known deadly Vibrio vulnificus in groundwater has been found based on OTU annotation analysis. However, there are still many OTUs that have not been identified and studied. Therefore, potential human pathogens in seawater intrusion areas still need to be further evaluated.

\section{CONCLUSIONS}

Seawater intrusion caused groundwater pollution in coastal areas is becoming more and more serious. This study integrated the hydrogeological investigation, microbial ecology and data analysis to investigate the impacts of seawater intrusion on the groundwater microbial communities in four shallow aquifers in the east coast of the PRD for the first time.

In summary, seawater intrusion increased the salinity and ions concentration $\left(\mathrm{Cl}^{-} 、 \mathrm{Na}^{+} 、 \mathrm{SO}_{4}{ }^{2-} 、 \mathrm{Mg}^{2+} 、 \mathrm{Ca}^{2+}\right)$ of groundwater, turned the water type from $\mathrm{HCO}_{3}-\mathrm{Ca}$ to $\mathrm{Cl}^{*} \mathrm{HCO}_{3}{ }^{-}$ $\mathrm{Na}^{*} \mathrm{Ca}$ and $\mathrm{Cl}^{*} \mathrm{SO}_{4}-\mathrm{Na}{ }^{*} \mathrm{Mg}$. The seawater intrusion is ongoing in profile DBH, the northwest of Shenzhen city, and the increasing impacts of human activities makes groundwater pollution not optimistic. The groundwater has $\mathrm{A}$ higher abundance and evenness of microbial community were observed in $\mathrm{Cl}^{*} \mathrm{SO}_{4}{ }^{-}$ $\mathrm{Na}^{*} \mathrm{Mg}$ type and $\mathrm{Cl}^{*} \mathrm{HCO}_{3}-\mathrm{Na}^{*} \mathrm{Ca}$ type groundwater, respectively, indicated that the community structure is affected by water type change. In the $\mathrm{Cl}^{*} \mathrm{SO}_{4}-\mathrm{Na}^{*} \mathrm{Mg}$ type groundwater, Gammaproteobacteria species, Alphaproteobacteria species and Bacteroidia species are dominant. Alteromonadales have a strong correlation with environmental factors and contain more unannotated genera, in contrast, Gammaproteobacteria species is the dominant species, and Chitinophagales have a relatively strong correlation with environmental 
factors in $\mathrm{Cl}^{*} \mathrm{HCO}_{3}-\mathrm{Na} * \mathrm{Ca}$ type groundwater. The correlation between the microbial community and environmental factors is obviously different, salinity and ORP has a significant positive correlation with salt and brackish groundwater, respectively, indicates that the water type is the main environmental factor that determines the microbial community structure, and controlled by others environmental factors.

Seawater intrusion changes the diversity and structure of microbial community in fresh groundwater, and the function diversity will also be changed company with water type change, so the impacts of seawater intrusion in this region require further research.

\section{ACKNOWLEDGEMENTS}

This work was supported by the National Natural Science Foundation of China (Grant U1911205). Kang Yang: Investigation, Methodology, Visualization, Writing- original draft. Linjie Hu: Investigation, Geochemical analysis. Can Liu and Shengcai Huang: Investigation. Liang Feng and Jianmei Cheng: Supervision, Funding acquisition, Writing, Reviewing and Editing.

\section{DATA AVAILABILITY STATEMENT}

The data that supports the findings of this study are available in the supplementary material of this article.

\section{REFERENCES}

Adyasari, D., Hassenruck, C., Montiel, D., \& Dimova, N. (2020). Microbial community composition across a coastal hydrological system affected by submarine groundwater discharge (SGD). PLoS One, 15 (6), e0235235. doi:10.1371/journal.pone.0235235

Adyasari, D., Oehler, T., Afiati, N., \& Moosdorf, N. (2019). Environmental impact of nutrient fluxes associated with submarine groundwater discharge at an urbanized tropical coast. Estuarine, Coastal and Shelf Science, 221 , 30-38. doi:10.1016/j.ecss.2019.03.009

Ashok Kumar, J., Vinaya Kumar, K., Avunje, S., Akhil, V., Ashok, S., Kumar, S., . . . Vijayan, K. K. (2020). Phylogenetic relationship among brackishwater Vibrio species. Evol Bioinform, 16 , 1-8. doi: $10.1177 / 1176934320903288$

Babu, D. S. S., Khandekar, A., Bhagat, C., Singh, A., Jain, V., Verma, M., . . . Kumar, M. (2021). Evaluation, effect and utilization of submarine groundwater discharge for coastal population and ecosystem: A special emphasis on Indian coastline. J Environ Manage, 277 , 111362. doi:10.1016/j.jenvman.2020.111362

Campbell, B. J., \& Kirchman, D. L. (2013). Bacterial diversity, community structure and potential growth rates along an estuarine salinity gradient. ISME J, 7 (1), 210-220. doi:10.1038/ismej.2012.93

Chandrajith, R., Diyabalanage, S., Premathilake, K. M., Hanke, C., van Geldern, R., \& Barth, J. A. C. (2016). Controls of evaporative irrigation return flows in comparison to seawater intrusion in coastal karstic aquifers in northern Sri Lanka: Evidence from solutes and stable isotopes. Sci Total Environ, 548-549, 421-428. doi:10.1016/j.scitotenv.2016.01.050

Chen, L., Hu, B. X., Dai, H., Zhang, X., Xia, C. A., \& Zhang, J. (2019). Characterizing microbial diversity and community composition of groundwater in a salt-freshwater transition zone. Sci Total Environ, 678, 574-584. doi:10.1016/j.scitotenv.2019.05.017

Cheng, X., Yun, Y., Wang, H., Ma, L., Tian, W., Man, B., \& Liu, C. (2021). Contrasting bacterial communities and their assembly processes in karst soils under different land use. Sci Total Environ, 751 , 142263. doi:10.1016/j.scitotenv.2020.142263

Crump, B. C., Hopkinson, C. S., Sogin, M. L., \& Hobbie, J. E. (2004). Microbial biogeography along an estuarine salinity gradient: combined influences of bacterial growth and residence time. Appl Environ Microbiol, 70 (3), 1494-1505. doi:10.1128/aem.70.3.1494-1505.2004 
Farid, I., Trabelsi, R., Zouari, K., Abid, K., \& Ayachi, M. (2013). Hydrogeochemical processes affecting groundwater in an irrigated land in Central Tunisia. Environmental Earth Sciences, 68 (5), 1215-1231. doi:10.1007/s12665-012-1788-7

Gan, H. M., Chew, T. H., Tay, Y.-L., Lye, S. F., \& Yahya, A. (2012). Genome sequence of Hydrogenophaga sp. Strain PBC, a 4-Aminobenzenesulfonate-degrading bacterium. Journal of Bacteriology, 194 (17), 47594760. doi:10.1099/mic.0.059550-010.1128/JB.00990-12

Gan, H. M., Shahir, S., \& Yahya, A. (2012). Cloning and functional analysis of the genes coding for 4-aminobenzenesulfonate 3,4-dioxygenase from Hydrogenophaga sp. PBC. Microbiology, 158 (Pt 8), 19331941. doi:10.1099/mic.0.059550-0

Ghyben, W. (1988). Nota in Verband met de Voorgenomen Putboering Nabij Amsterdam. Tijdschr. Kon. Inst. Ing, 8-22.

Goldscheider, N., Hunkeler, D., \& Rossi, P. (2006). Review: microbial biocenoses in pristine aquifers and an assessment of investigative methods. Hydrogeology Journal, 14 (6), 926-941. doi:10.1007/s10040-005-0009-9

Griebler, C., \& Lueders, T. (2009). Microbial biodiversity in groundwater ecosystems. Freshwater Biology, 54 (4), 649-677. doi:10.1111/j.1365-2427.2008.02013.x

Gyraite, G., Katarzyte, M., \& Schernewski, G. (2019). First findings of potentially human pathogenic bacteria Vibrio in the south-eastern Baltic Sea coastal and transitional bathing waters. Mar Pollut Bull, 149 , 110546. doi:10.1016/j.marpolbul.2019.110546

Ham, B., Kwon, J. S., Boyanov, M. I., O'Loughlin, E. J., Kemner, K. M., \& Kwon, M. J. (2021). Geochemical and microbial characteristics of seepage water and mineral precipitates in a radwaste disposal facility impacted by seawater intrusion and high alkalinity. J Environ Manage, 285 , 112087. doi:10.1016/j.jenvman.2021.112087

He, Y., Huang, D., Li, S., Shi, L., Sun, W., Sanford, R. A., . . . Dong, Y. (2021). Profiling of microbial communities in the sediments of Jinsha River watershed exposed to different levels of impacts by the Vanadium industry, Panzhihua, China. Microb Ecol . doi:10.1007/s00248-021-01708-9

Henriques, I. S., Alves, A., Tacão, M., Almeida, A., Cunha, Â., \& Correia, A. (2006). Seasonal and spatial variability of free-living bacterial community composition along an estuarine gradient (Ria de Aveiro, Portugal). Estuarine, Coastal and Shelf Science, 68 (1-2), 139-148. doi:10.1016/j.ecss.2006.01.015

Hery, M., Volant, A., Garing, C., Luquot, L., Elbaz Poulichet, F., \& Gouze, P. (2014). Diversity and geochemical structuring of bacterial communities along a salinity gradient in a carbonate aquifer subject to seawater intrusion. FEMS Microbiol Ecol, 90 (3), 922-934. doi:10.1111/1574-6941.12445

Herzberg, A. (1901). Die Wasserversorgung einiger Nordseeader.Journal Gasbeleuchtung und Wasserversorgung, 44 , 815-819. doi:10.1016/j.watres.2016.02.039

Hwang, D.-W., Lee, Y.-W., \& Kim, G. (2005). Large submarine groundwater discharge and benthic eutrophication in Bangdu Bay on volcanic Jeju Island, Korea. Limnol. Oceanogr., 50 (5), 1393-1403.

Jankowski, K. L., Tornqvist, T. E., \& Fernandes, A. M. (2017). Vulnerability of Louisiana's coastal wetlands to present-day rates of relative sea-level rise. Nat Commun, 8 , 14792. doi:10.1038/ncomms14792

Jiao, J. J., Wang, Y., Cherry, J. A., Wang, X.-S., Zhi, B., Du, H., \& Wen, D. (2010). Abnormally high ammonium of natural origin in a coastal aquifer-aquitard system in the Pearl River Delta, China.Environmental Science $E$ T Technology, 44 (19), 7470-7475. doi:10.1021/es1021697

Kim, K.-Y., Seong, H., Kim, T., Park, K.-H., Woo, N.-C., Park, Y.-S., . . Park, W.-B. (2006). Tidal effects on variations of fresh-saltwater interface and groundwater flow in a multilayered coastal aquifer on a volcanic island (Jeju Island, Korea). Journal of Hydrology, 330 (3-4), 525-542. doi:10.1016/j.jhydrol.2006.04.022 
Kima, Y., Leeb, K.-S., Koha, D.-C., Leea, D.-H., Leea, S.-G., Kohd, W.-B. P.-W., \& Wooe, N.-C. (2003). Hydrogeochemical and isotopic evidence of groundwater salinization in a coastal aquifer: a case study in Jeju volcanic island, Korea. Journal of Hydrology, 270 , 282-294.

Kwon, E., Park, J., Park, W. B., Kang, B. R., \& Woo, N. C. (2021). Nitrate contamination of coastal groundwater: sources and transport mechanisms along a volcanic aquifer. Sci Total Environ, 768 , 145204. doi:10.1016/j.scitotenv.2021.145204

Lee, K. H., Wang, Y. F., Wang, Y., Gu, J. D., \& Jiao, J. J. (2018). Abundance and diversity of aerobic/anaerobic ammonia/ammonium-oxidizing microorganisms in an ammonium-rich aquitard in the Pearl River Delta of South China. Microb Ecol, 76 (1), 81-91. doi:10.1007/s00248-016-0815-8

Liu, K., Jiao, J. J., \& Gu, J. D. (2014). Investigation on bacterial community and diversity in the multilayer aquifer-aquitard system of the Pearl River Delta, China. Ecotoxicology, 23 (10), 2041-2052. doi:10.1007/s10646-014-1311-x

Liu, Y., Lin, Q., Feng, J., Yang, F., Du, H., Hu, Z., \& Wang, H. (2020). Differences in metabolic potential between particle-associated and free-living bacteria along Pearl River Estuary. Sci Total Environ, 728 , 138856. doi:10.1016/j.scitotenv.2020.138856

Llopis-Albert, C., \& Pulido-Velazquez, D. (2014). Discussion about the validity of sharp-interface models to deal with seawater intrusion in coastal aquifers. Hydrological Processes, 28 (10), 3642-3654. doi:10.1002/hyp.9908

Logares, R., Brate, J., Bertilsson, S., Clasen, J. L., Shalchian-Tabrizi, K., \& Rengefors, K. (2009). Infrequent marine-freshwater transitions in the microbial world. Trends Microbiol, 17 (9), 414-422. doi:10.1016/j.tim.2009.05.010

Lu, F.-H., Ni, H.-G., Liu, F., \& Zeng, E. Y. (2009). Occurrence of nutrients in riverine runoff of the Pearl River Delta, South China.Journal of Hydrology, 376 (1-2), 107-115. doi:10.1016/j.jhydrol.2009.07.018

Luther, G. W., Sundby, B., Lewis, B. L., Brendel, P. J., \& Silverberg, N. (1997). Interactions of manganese with the nitrogen cycle: alternative pathways to dinitrogen. Geochirnica et Cosmochimica Acta, 61 (19), 4043-4052.

Ma, J., Liu, H., Tong, L., Wang, Y., Chen, R., Liu, S., . . Cai, L. (2019). Relationships between microbial communities and groundwater chemistry in two pristine confined groundwater aquifers in central China. Hydrological Processes, 33 (14), 1993-2005. doi:10.1002/hyp.13437

Mai, Y. Z., Lai, Z. N., Li, X. H., Peng, S. Y., \& Wang, C. (2018). Structural and functional shifts of bacterioplanktonic communities associated with spatiotemporal gradients in river outlets of the subtropical Pearl River Estuary, South China. Mar Pollut Bull, 136 , 309-321. doi:10.1016/j.marpolbul.2018.09.013

Paver, S. F., Muratore, D., Newton, R. J., \& Coleman, M. L. (2018). Reevaluating the salty divide phylogenetic: specificity of transitions between marine and freshwater systems. mSystems, 3 (6), e00232-00218.

Qi, S.-Z., \& Qiu, Q.-L. (2011). Environmental hazard from saltwater intrusion in the Laizhou Gulf, Shandong Province of China. Natural Hazards, 56 (3), 563-566. doi:10.1007/s11069-010-9686-3

Reddy, A. G. S., Saibaba, B., \& Sudarshan, G. (2012). Hydrogeochemical characterization of contaminated groundwater in Patancheru industrial area, southern India. Environmental Monitoring and Assessment, 184 (6), 3557-3576.

Sakr, S. A. (1999). Validity of a sharp-interface model in a confined coastal aquifer. Hydrogeology Journal, 7 , 155-160.

Sang, S., Dai, H., Hu, B. X., Hao, Y., Zhou, T., \& Zhang, J. (2019). The study of hydrogeochemical environments and microbial communities along a groundwater salinity gradient in the Pearl River Delta, China.Water, 11 (4), 804-822. doi:10.3390/w11040804 
Sang, S., Zhang, X., Dai, H., Hu, B. X., Ou, H., \& Sun, L. (2018). Diversity and predictive metabolic pathways of the prokaryotic microbial community along a groundwater salinity gradient of the Pearl River Delta, China. Sci Rep, 8 (1), 17317. doi:10.1038/s41598-018-35350-2

Santoro, A. E. (2010). Microbial nitrogen cycling at the saltwater-freshwater interface. Hydrogeology Journal, 18 (1), 187-202. doi:10.1007/s10040-009-0526-z

Schloss, P. D., Westcott, S. L., Ryabin, T., Hall, J. R., Hartmann, M., Hollister, E. B., . . Weber, C. F. (2009). Introducing mothur: open-source, platform-independent, community-supported software for describing and comparing microbial communities. Applied and Environmental Microbiology, 75 (23), 7537-7541.

Smith, R. L., Böhlke, J. K., Song, B., \& Tobias, C. R. (2015). Role of Anaerobic Ammonium Oxidation (Anammox) in nitrogen removal from a freshwater aquifer. Environmental Science \&5 Technology, 49 (20), 12169-12177. doi:10.1021/acs.est.5b02488

Teng, Y., Su, J., Wang, J., Dai, N., Li, J., Song, L., \& Zuo, R. (2014). Soil microbial community response to seawater intrusion into coastal aquifer of Donghai Island, South China. Environmental Earth Sciences, 72 (9), 3329-3338. doi:10.1007/s12665-014-3236-3

Unno, T., Kim, J., Kim, Y., Nguyen, S. G., Guevarra, R. B., Kim, G. P., . . . Sadowsky, M. J. (2015). Influence of seawater intrusion on microbial communities in groundwater. Sci Total Environ, 532, 337-343. doi:10.1016/j.scitotenv.2015.05.111

Venancio, C., Castro, B. B., Ribeiro, R., Antunes, S. C., Abrantes, N., Soares, A., \& Lopes, I. (2018). Sensitivity of freshwater species under single and multigenerational exposure to seawater intrusion.Philos Trans R Soc Lond B Biol Sci, 374 (1764). doi:10.1098/rstb.2018.0252

Wang, Y., \& Jiao, J. J. (2012). Origin of groundwater salinity and hydrogeochemical processes in the confined Quaternary aquifer of the Pearl River Delta, China. Journal of Hydrology, 438-439 , 112-124. doi:10.1016/j.jhydrol.2012.03.008

Wang, Y., Jiao, J. J., Cherry, J. A., \& Lee, C. M. (2013). Contribution of the aquitard to the regional groundwater hydrochemistry of the underlying confined aquifer in the Pearl River Delta, China. Sci Total Environ, 461-462 , 663-671. doi:10.1016/j.scitotenv.2013.05.046

Werner, A. D., Bakker, M., Post, V. E. A., Vandenbohede, A., Lu, C., Ataie-Ashtiani, B., . . Barry, D. A. (2013). Seawater intrusion processes, investigation and management: Recent advances and future challenges. Advances in Water Resources, 51 , 3-26. doi:10.1016/j.advwatres.2012.03.004

Widney, S. E., Smith, D., Herbert, E. R., Schubauer-Berigan, J. P., Li, F., Pennings, S. C., \& Craft, C. B. (2019). Chronic but not acute saltwater intrusion leads to large release of inorganic $\mathrm{N}$ in a tidal freshwater marsh. Sci Total Environ, 695 , 133779. doi:10.1016/j.scitotenv.2019.133779

Yang, J., Jiang, H., Wu, G., Liu, W., \& Zhang, G. (2016). Distinct factors shape aquatic and sedimentary microbial community structures in the lakes of Western China. Front Microbiol, 7 , 1782-1790. doi:10.3389/fmicb.2016.01782

Yang, Q. C., Li, Z. J., Ma, H. Y., Wang, L. C., \& Martin, J. D. (2016). Identification of the hydrogeochemical processes and assessment of groundwater quality using classic integrated geochemical methods in the Southeastern part of Ordos basin, China. Environmental Pollution, 218 , 879-888.

Ye, Q., Liu, J., Du, J., \& Zhang, J. (2015). Bacterial diversity in submarine groundwater along the coasts of the Yellow Sea. Front Microbiol, 6 , 1519. doi:10.3389/fmicb.2015.01519

Zhang, X., Hu, B. X., Ren, H., \& Zhang, J. (2018). Composition and functional diversity of microbial community across a mangrove-inhabited mudflat as revealed by $16 \mathrm{~S}$ rDNA gene sequences. Sci Total Environ, 633 , 518-528. doi:10.1016/j.scitotenv.2018.03.158 
Zhang, X., Qi, L., Li, W., Hu, B. X., \& Dai, Z. (2021). Bacterial community variations with salinity in the saltwater-intruded estuarine aquifer. Sci Total Environ, 755 (Pt 1), 142423. doi:10.1016/j.scitotenv.2020.142423

Zong, Y., Huang, G., Switzer, A. D., Yu, F., \& Yim, W. W. S. (2009). An evolutionary model for the Holocene formation of the Pearl River delta, China. The Holocene, 19 (1), 129-142. doi:10.1177/0959683608098957

\section{SUPPORTING INFORMATION}

Additional supporting information may be found online in the Supporting Information section at the end of the article.

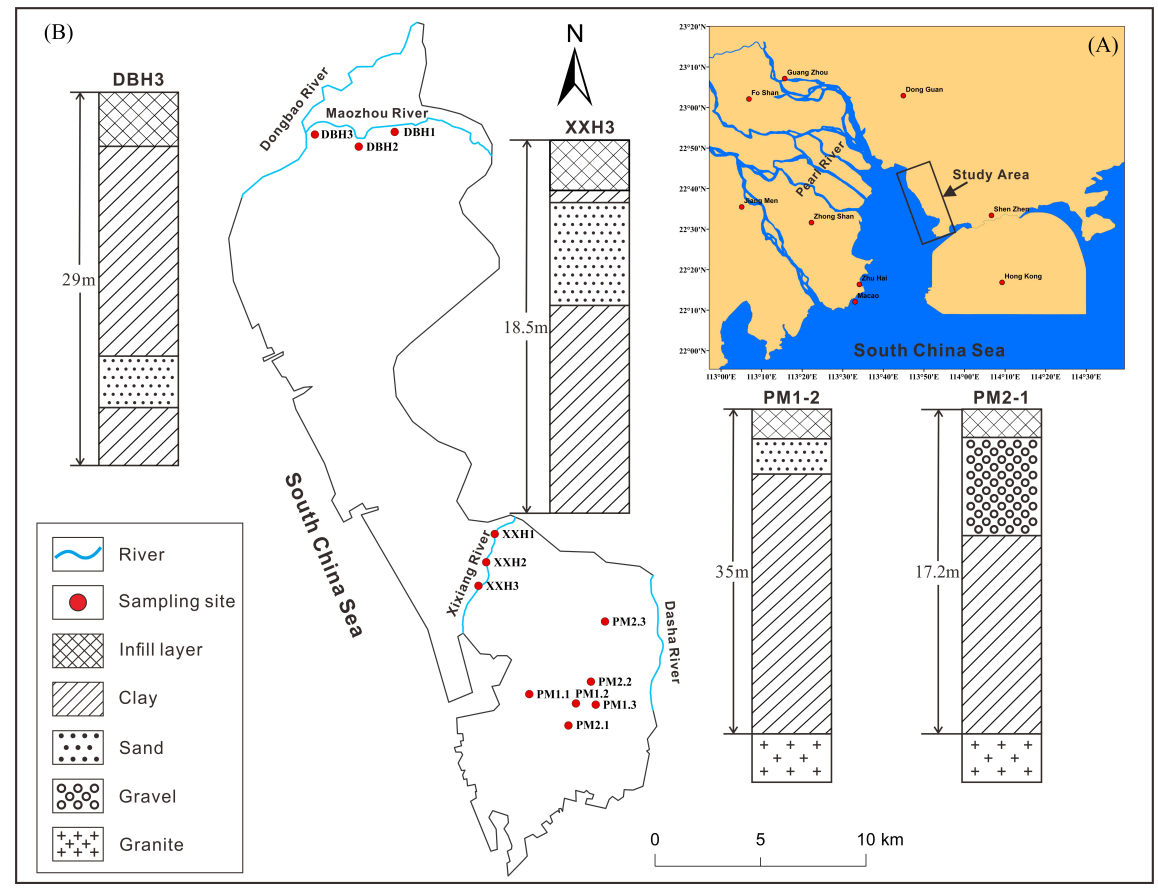




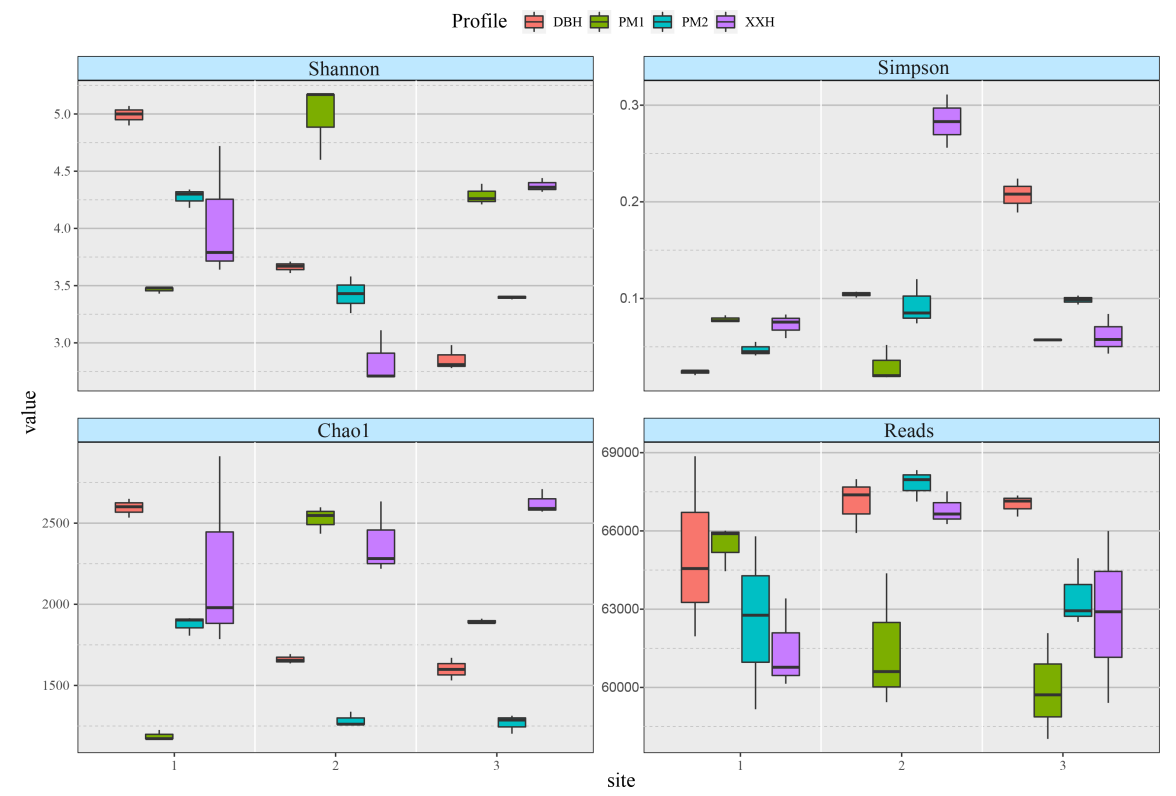

\section{Hosted file}

Figure 3.docx available at https://authorea.com/users/451099/articles/549348-compare-thechanges-of-groundwater-type-and-microbial-community-in-four-shallow-aquifers-affectedby-seawater-intrusion-in-the-east-coastal-of-pearl-river-delta

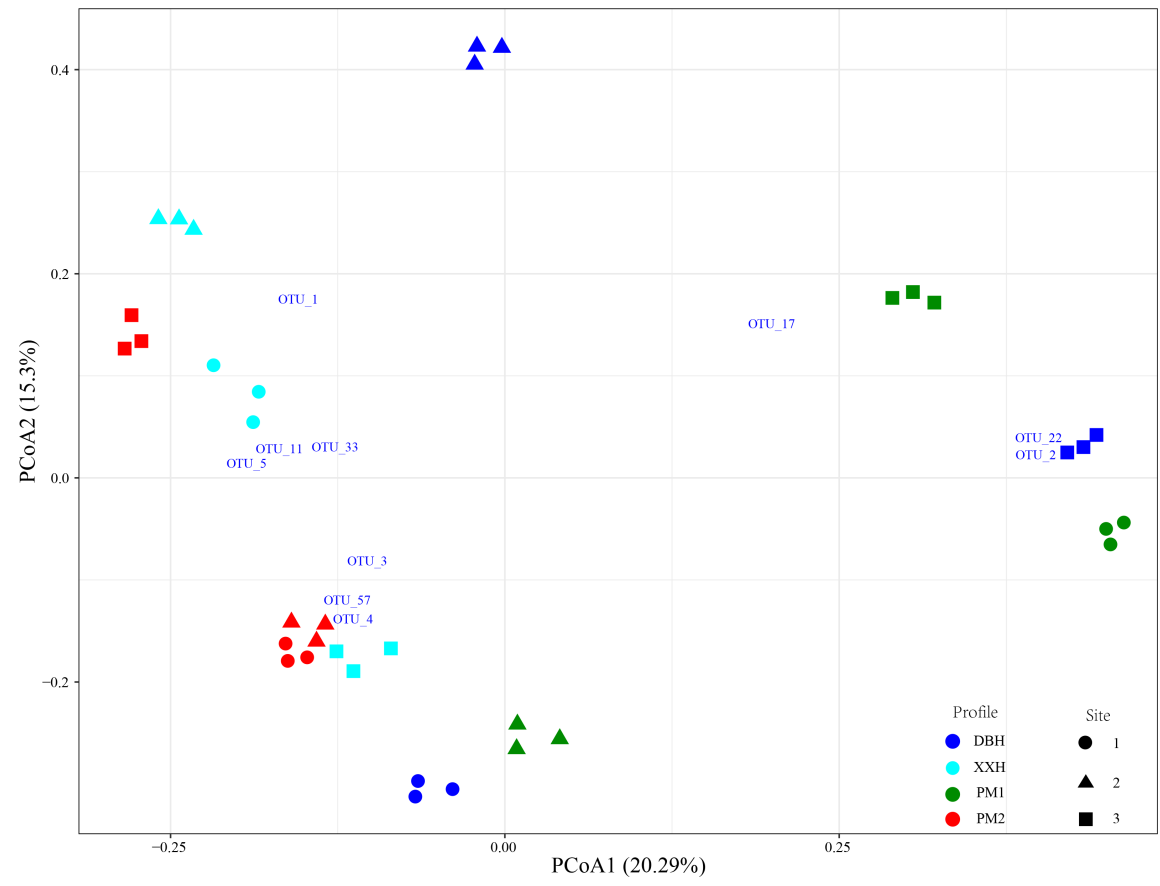


(A)

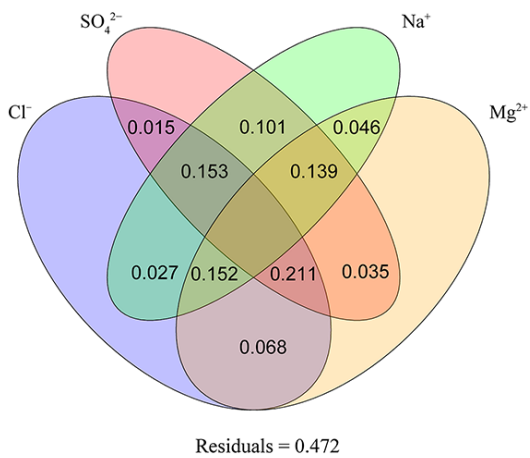

(B)
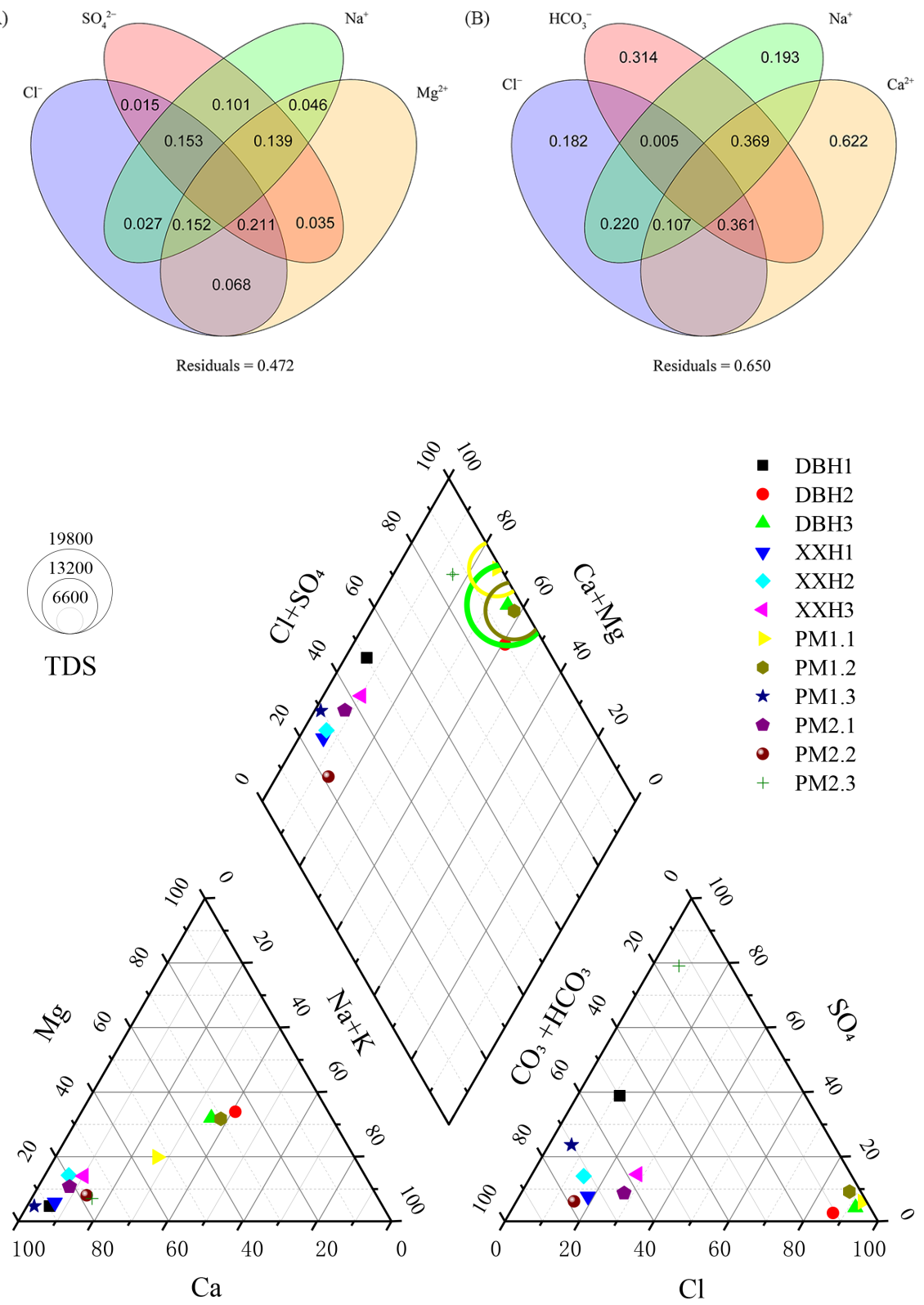


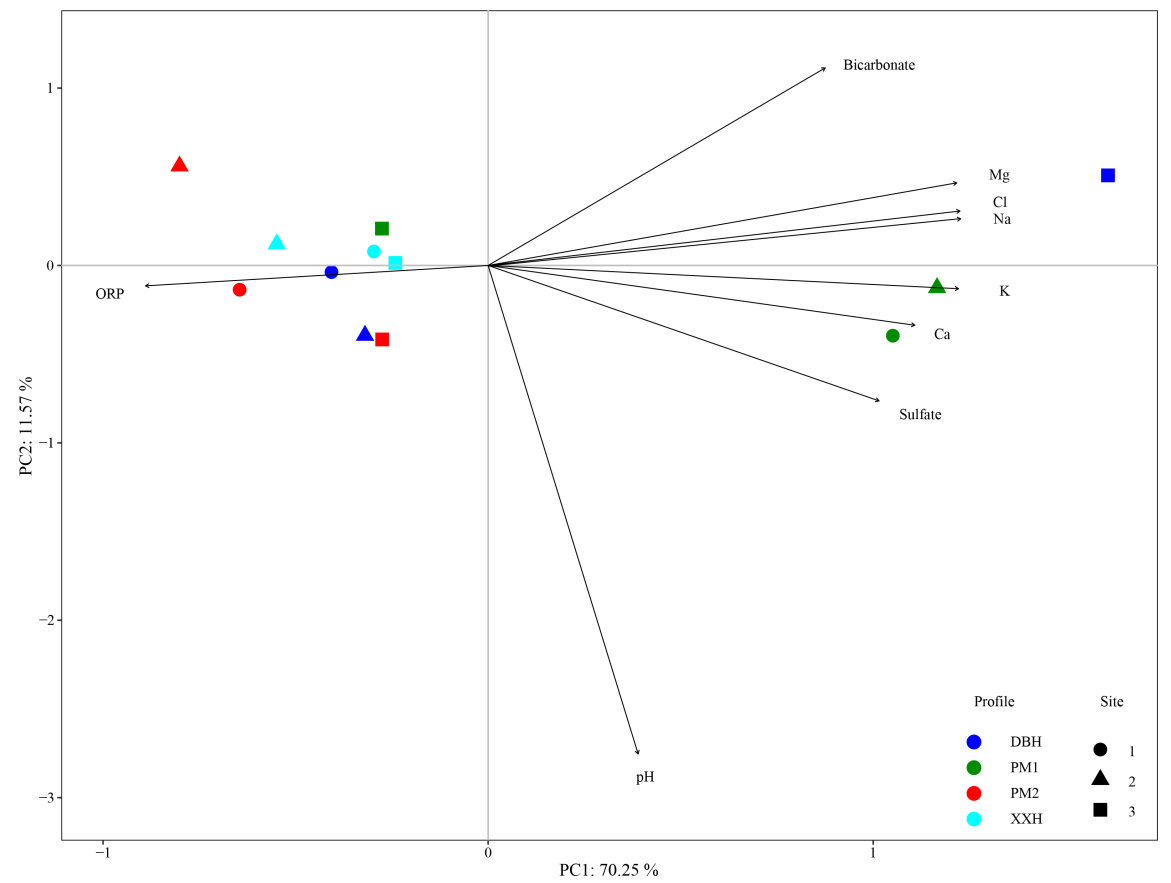

\section{Hosted file}

Table 1.docx available at https://authorea.com/users/451099/articles/549348-compare-thechanges-of-groundwater-type-and-microbial-community-in-four-shallow-aquifers-affectedby-seawater-intrusion-in-the-east-coastal-of-pearl-river-delta 